\title{
Importância do uso de animais experimentais para a medicina humana
}

Nestor Schor' ${ }^{1}$ Mirian A. Boim²

N os últimos tempos têm ocorrido várias manifestações da sociedade, traduzindo sua profunda preocupação com o uso de animais em laboratórios de pesquisa. Esta preocupação decorre do fato de que, até recentemente, não existia um controle ético na utilização de tais modelos animais. Relatos degradantes com registros de experimentos bárbaros, sob a atual óptica ética contemporânea. Como resposta a essa desordenada utilização de animais de experimentação, uma reação esperada ocorreu, porém, sem uma modulação adequada, sendo que vários grupos ou mesmo indivíduos isoladamente, manifestam suas propostas, muitas vezes extremas, propondo banir animais para o fim de pesquisa médica.

Entretanto, a pesquisa com animais tem sido uma parte integrante e imprescindível do desenvolvimento da medicina moderna, evitando a morte de um número incalculável de pessoas e prevenindo imenso sofrimento humano. Por outro lado, é indiscutível que os centros de pesquisa e/ ou ensino que utilizam animais devam submeter seus projetos aos Comitês de Ética Institucionais. Nestes, os referidos projetos são avaliados por indivíduos sem conflito de interesse (como regra esses comitês são constituídos além de cientistas, por outros profissionais de áreas não biológicas e representantes da sociedade e das Igrejas), para que emitam seu parecer sobre a necessidade e os cuidados a serem instituídos para a "defesa animal”. No estágio atual da ciência mundial, várias situações não podem excluir o uso de animais. Como exemplo, citamos algumas delas:

- Avaliação do efeito de células tronco no reparo de órgãos

- $\quad$ O efeito de genes (aumento ou redução de sua expressão) sobre o organismo (uso de animais transgênicos)

- Estudo de células ou tecidos que devem ser obtidos de animais, para estudos de biologia celular e molecular

- Estudos de toxicidade pré-clínica, que obrigatoriamente envolvem avaliação dos efeitos colaterais em animais

- Impacto de técnicas cirúrgicas inovadoras

- Teste de novos materiais utilizados em seres humanos
- Treinamento cirúrgico sofisticado na ausência de modelos de plástico (ou outros)

- Estudo em modelos animais de doenças humanas como o diabetes mellitus, hipertensão, aterosclerose, obesidade, insuficiência renal, epilepsia, diversos tipos de câncer, além de muitas outras

- Desenvolvimento de vacinas e anticorpos contra novas doenças

- Desenvolvimento de animais que potencialmente poderiam fornecer órgãos ou tecidos para transplante

- $\quad$ etc ,etc , etc....

Modelos computacionais e cultura de células são excelentes metodologias iniciais que podem e devem ser utilizadas para se reduzir o número de animais a serem utilizados em pesquisa. Porém, testes finais em animais devem ser obrigatoriamente necessários antes que se possa introduzir um novo tratamento ou droga para uso em seres humanos. Lembre-se, oportunamente, que praticamente todas as drogas encontradas nas farmácias e os tratamentos para doenças humanas dos quais confortavelmente fazemos uso hoje foram desenvolvidos após testes em animais.

Desta forma, concordamos sim com o controle ético estrito e rigoroso sobre o uso de animais de experimentação, pois entendemos que uma ciência moderna só se constrói com ética. Sabemos também que a ética representa um dos mais profundos sentimentos de justiça de um povo e que evolui ou se modifica ao longo do tempo, sendo necessária uma atividade contínua de reflexão e re-avaliações.

Temos muito receio de posturas absolutas de tudo ou nada, que podem facilmente representar um retrocesso na busca por melhores condições de vida para todos. Seria, sem dúvida, mais útil se possuíssemos uma legislação pertinente, em que fossem previstos mecanismos de controle de "práticas cruéis" desnecessárias, de forma clara e objetiva, a fim de permitir a sua rápida e efetiva implementação, com a efetiva participação da sociedade.

\footnotetext{
1 Professor Titular de Medicina da Universidade Federal de São Paulo (UNIFESP), Ex-Pró-Reitor de Pós-Graduação e Pesquisa da UNIFESP, Ex-Presidente da Sociedade Brasileira de Nefrologia e da Sociedade Brasileira de Investigação Clínica, Membro Titular da Academia Brasileira de Ciências, Membro Titular da Academia Nacional de Medicina. E-mail: nestor@nefro.epm.br

2 Professora Pesquisadora e Professora Afiliada da Disciplina de Nefrologia da UNIFESP, Coordenadora do Programa de Pós-Graduação da Disciplina de Nefrologia da UNIFESP, Professora Doutora e Livre Docente da UNIFESP, Ex-Fellow da Harvard Medical School, E-mail: mirian@nefro.epm.br
} 